\title{
Dissociation and Degradation of Thiol-Modified DNA
}

\section{on Gold Nanoparticles in Aqueous and Organic Solvents}

Nishi Bhatt, Po-Jung Jimmy Huang, Neeshma Dave, and Juewen Liu*

\author{
Department of Chemistry, Waterloo Institute for Nanotechnology, University of Waterloo, 200 \\ University Avenue West, Waterloo, Ontario, N2L 3G1, Canada
}

liujw@uwaterloo.ca

\section{Received: January 19, 2011}

Revised: March 6, 2011

Published: April 22, 2011

This document is the Accepted Manuscript version of a Published Work that appeared in final form in Langmuir, copyright (C) American Chemical Society after peer review and technical editing by publisher. To access the final edited and published work see http://dx.doi.org/10.1021/la200241d 


\section{ABSTRACT}

Gold nanoparticles functionalized with thiol-modified DNA have been widely used in making various nanostructures, colorimetric biosensors, and drug delivery vehicles. Over the past 15 years, significant progress has been made to improve the stability of such functionalized nanoparticles. The stability of the gold-thiol bond in this system, however, has not been studied in a systematic manner. Most information on the gold-thiol bond was obtained from the study of self-assembled monolayers (SAMs). In this study, we employed two fluorophore-labeled and thiol-modified DNAs. The long-term stability of the thiol-gold bond as a function of time, salt, temperature, $\mathrm{pH}$, and organic solvent has been studied. We found that the bond spontaneously dissociated under all tested conditions. The dissociation was favored at high salt, high $\mathrm{pH}$, high temperature and little DNA degradation was observed in our system. Most organic solvents showed a moderate protection effect on the gold-thiol bond. The stability of the gold-thiol bond in the DNA system was also compared with that in SAMs. While there are many similarities, we also observed opposite trends for the salt and ethanol effect. This study suggests that the purified DNA-functionalized gold nanoparticles should be freshly prepared and used in a day or two. Long term storage should be carried out at relatively low temperature in low salt and slight acidic buffers.

\section{INTRODUCTION}

Since 1996, thiol-modified DNA has become a widely used reagent for functionalization of gold nanoparticles (AuNPs) and such nanoparticles have become one of the corner stones in bionanotechnology. ${ }^{1-11}$ They are widely used for making novel nanostructure, ${ }^{12-19}$ delivery of therapeutic agents, ${ }^{20}$ and constructing highly sensitive sensors for metal ions, ${ }^{21}$ small molecules,${ }^{22}$ nucleic acids,${ }^{23}$ proteins,${ }^{24}$ and even whole cells. ${ }^{25}$ AuNPs are attractive for these applications for the following reasons. First, mono-dispersed AuNPs ranging from 1.4 to $>100 \mathrm{~nm}$ can be routinely synthesized by the simple reduction chemistry and are also commercially available. Second, the chemistry of DNA conjugation is well-established and easy to achieve. Third, AuNPs have a very high extinction coefficient (e.g. over three

orders of magnitude higher than most organic dyes) and a distance-dependent optical property. ${ }^{26,27}$ When 
AuNPs are individually dispersed, the color is red. Upon aggregation, the color changes to purple or blue due to the coupling of AuNP surface plasmon. Therefore, by engineering different mechanisms to control the distance among AuNPs, highly sensitive colorimetric sensors can be obtained.

For most applications, it is important to maintain a stable linkage between AuNPs and DNA. The thiolgold bond stability has been extensively studied in the context of self-assembled monolayers (SAMs). It is known that such a bond is susceptible to oxidation in air and in water, resulting in compromised longterm stability. ${ }^{28-38}$ On the other hand, thiol-modified DNAs do not form SAMs on gold due to a lack of lateral hydrophobic interactions among DNA and DNA does not closely pack on the gold surface. ${ }^{39}$ For example, the generally accepted high coverage thiol SAM structure is the $(\sqrt{3} \times \sqrt{3}) R 30^{\circ}$ epitaxial arrangement on $\mathrm{Au}(111) .{ }^{40}$ Based on this model, a thiol density of $4.6 / \mathrm{nm}^{2}$ can be calculated. On the other hand, the thiol-DNA density on planar $\mathrm{Au}$ is only $\sim 0.056 \mathrm{DNA} / \mathrm{nm}^{2}$ and on highly curved $10 \mathrm{~nm}$ AuNP is $\sim 0.2 \mathrm{DNA} / \mathrm{nm}^{2}{ }^{41}$ Therefore, the SAM density is one to two orders of magnitude higher than that of DNA; the knowledge obtained from studying SAMs may not be completely applicable to the DNAgold interface.

Over the past 15 years, research efforts in trying to improve the stability of the DNA-gold linkage have mostly focused on two areas. First, instead of using mono-thiol modifications, DNAs modified with two and even three thiol groups were shown to significantly improve the conjugate stability. ${ }^{42-45}$ However, such multidentate thiol DNAs are more expensive to synthesize or are not commercially available, and mono-thiol DNA is still the most widely used reagent. On the other hand, fundamental understandings on the AuNP and thiol-DNA chemistry allowed significant improvements of AuNP stability. For example, the AuNP stability and DNA density are affected by particle size ${ }^{41}$ DNA sequence, ${ }^{46}$ DNA secondary structure, ${ }^{47}$ small molecule thiol compounds, ${ }^{48}$ thiol exchange,${ }^{49}$ the presence of surfactants and sonication treatment. ${ }^{50,51}$ Most of these works have focused on the saltdependent colloidal stability of AuNPs. The hypothesis is that a more stable DNA linkage and a higher DNA density should allow AuNPs to be stable in a higher salt buffer. Colloidal stability is important for practical applications since many assays may 
require a high ionic strength. These experiments, however, did not directly exam on the stability of the thiol-gold bond.

In a typical experiment to functionalize AuNPs, an excess amount of thiol-modified DNA is incubated with AuNPs in the presence of progressively increased salt concentration. ${ }^{1,23,26,50,52}$ For most applications, the free DNAs are removed by centrifugation to avoid interference and the purified AuNPs are used immediately. While such operations are commonly accepted in the laboratory, for practical applications, it is desirable to have pre-purified AuNPs to avoid the centrifugation step by end-users. Therefore, it is also important to know the stability of the purified DNA-AuNP hybrid. While desorption of thiol compounds has been extensively studied in the context of electrochemistry and SAMs, ${ }^{28-38,40,53-}$ 58 few reports can be found on the dissociation of DNA from nanoparticles. ${ }^{59}$ In this work, we systematically studied the kinetics of DNA dissociation as a function of ionic strength, temperature, $\mathrm{pH}$, and organic solvent. We found that the most desirable condition for storage of purified DNAfunctionalized AuNPs is at low temperature with a low ionic strength and low $\mathrm{pH}$.

\section{MATERIALS AND METHODS}

Materials. All DNA samples were purchased from Integrated DNA Technologies (Coralville, IA) and purified by HPLC. The DNA sequences for DNA1 is 5'-FAM-ATGCGGAGGAAGGT TTT-SH-3' and for DNA2 is 5'-SH-T(FAM)TCCCAGGTTCTCT-3'. All the solvents, acetic acid and hydrochloric acid were purchased from VWR. Sodium chloride, magnesium chloride, sodium acetate, EDTA, 4Morpholineethanesulfonate (MES), 4-(2-hydroxyethyl)piperazine-1-ethanesulfonate (HEPES), and Tris(hydroxymethyl)aminomethane (Tris) were purchased from Mandel Scientific (Guelph, Ontario, Canada). AuNPs (13 nm diameter) were synthesized following literature reported procedures by citrate reduction. ${ }^{52}$ All the buffer solutions were freshly prepared and filtered and Millipore water was used for all the experiments.

DNA Release Assays. Thiol-modified DNAs were attached to AuNPs using literature reported procedures and the final DNA concentration was $2.6 \mu \mathrm{M}$. DNA-functionalized AuNPs $(\sim 9 \mathrm{nM})$ were 
washed by repeated centrifugation at $15000 \mathrm{rpm}$ for $20 \mathrm{~min}$, removal of supernatant and re-disperse in buffer three times. The purified nanoparticles were dispersed in appropriate buffers and transferred into microcentrifuge tubes (50 $\mu \mathrm{L}$ each with AuNP concentration being $\sim 9 \mathrm{nM})$. At designated time points, the tubes were centrifuged at $15000 \mathrm{rpm}$ for $10 \mathrm{~min}$ and $25 \mu \mathrm{L}$ of the supernatant was transferred to another tube. After 15 days, the precipitated AuNPs were treated with $2 \mathrm{mM}$ beta-mercaptoethanol (BME) and diluted to $100 \mu \mathrm{L}$ with a buffer (25 mM HEPES, pH 7.6, $100 \mathrm{mM} \mathrm{NaCl}$ ). The previously collected supernatants were also diluted to $100 \mu \mathrm{L}$ with the same buffer. The fluorescence of all these supernatant solutions $\left(F_{s}\right)$ and BME treated AuNPs $\left(F_{p}\right)$ were measured and the fraction of release was determined to be $2 F_{s} /\left(F_{s}+F_{p}\right)$. All the experiments were run in triplicates. The fluorescence was quantified using a microplate reader (Molecular Devices, SpectraMax M5) with excitation at $485 \mathrm{~nm}$ and emission at 520 nm.

Effect of Organic Solvent. The AuNPs were purified by centrifugation as described above and dispersed in $25 \mathrm{mM}$ HEPES, pH 7.6 with a final AuNP concentration of $45 \mathrm{nM} .10 \mu \mathrm{L}$ of such AuNPs were then mixed with $40 \mu \mathrm{L}$ of various 100 and $50 \%$ solvents so that the final solvent concentrations were 80 and 40\%, respectively and the AuNP concentration was 9 nM. After a week, the AuNPs were centrifuged and the supernatant fluorescence was quantified. In another experiment, AuNPs were dispersed in 25 or $50 \%$ solvents with 100 or $200 \mathrm{mM} \mathrm{NaCl}$, respectively. The color of the AuNPs was recorded by a digital camera (Canon PowerShot SD 1200 IS). To remove the solvent, the AuNPs were centrifuged and the supernatant was displaced by water.

Effect of pH. To study the effect of pH, $500 \mathrm{mM}$ of the following buffer solutions were prepared: acetate buffer ( $\mathrm{pH} 4.0$ and 5.0), MES (pH 6.0), Tris-HCl (pH 7.0, 8.0, and 9.0). In a total volume of 50 $\mu \mathrm{L}$, each buffer concentration was at $50 \mathrm{mM}$ with no additional $\mathrm{NaCl}$ added. The AuNP concentration was $9 \mathrm{nM}$ for all the samples. After storing at room temperature for 3 and 6 days, the solutions were centrifuged and $25 \mu \mathrm{L}$ of the supernatant solution was mixed with $200 \mu \mathrm{L}$ of buffer (100 mM Tris-HCl, $\mathrm{pH}$ 8.3) to ensure that all the samples had the same high $\mathrm{pH}$, and the fluorescence was measured. 
Gel electrophoresis. To exam the integrity of DNA on AuNPs, the DNA on precipitated AuNPs was displaced by $2 \mathrm{mM}$ BME overnight. The released DNA was loaded into $15 \%$ denaturing polyacrylamide gel and the gel was documented by exciting at $302 \mathrm{~nm}$ and the emission was collected with a digital camera through a green filter (Alpha Innotech FluorChem FC2).

\section{RESULTS AND DISCUSSION}

Experiment Design. For a thiol-modified DNA to be fully functional on the AuNP surface, two types of chemical linkages have to remain intact. First, the Au-thiol bond ensures that the DNA is actually conjugated to the surface. Second, all the phosphodiester linkages in the DNA must be stable to ensure the integrity of DNA. To monitor the stability of these bonds as a function of time, two fluorescently labeled thiol-modified DNAs were used (Figure 1A). In DNA1, the fluorophore and thiol are respectively on the two DNA termini. If any linkage in DNA1 is cleaved, the fluorophore is released into solution. Free fluorophores and AuNPs can be conveniently separated using centrifugation. By simply monitoring the solution fluorescence, however, it is difficult to tell which type of bond is cleaved. To solve this problem, a second DNA (DNA2) with the fluorophore right next to the thiol was also tested (Figure 1B). In this case, DNA degradation should not produce a fluorescence change in the supernatant; and all the fluorescence must be due to the cleavage of the Au-thiol bond.

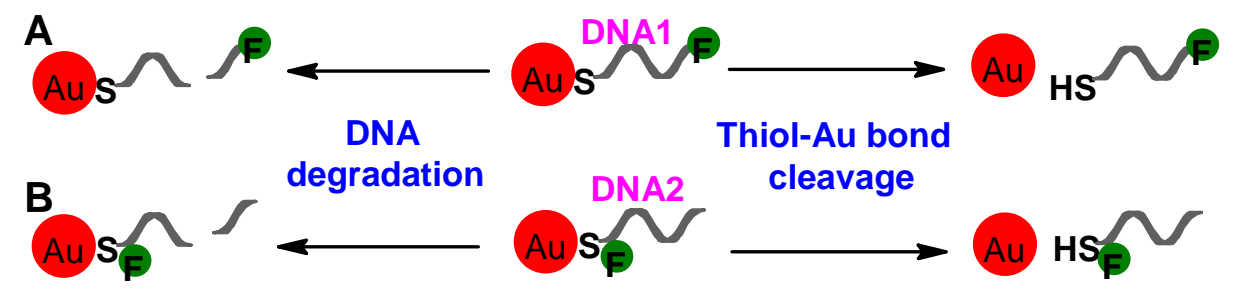

Figure 1. The use of fluorescently labeled and thiol-modified DNAs to study the release of DNA due to either DNA degradation or thiol-Au bond cleavage. (A) The FAM fluorophore is away from the thiol modification. (B) The FAM is internally labeled on the first thymine nucleotide and is right next to the thiol modification. 
DNA Dissociation Kinetics. DNA-functionalized AuNPs were prepared by mixing $2.6 \mu \mathrm{M}$ thiolDNA with 10 nM AuNPs. Since the maximally achievable DNA on such 13 nm AuNPs wais about 100 to 150, the DNA was in excess. ${ }^{41,60}$ The functionalized AuNPs were purified by centrifugation to remove free DNA in the supernatant and the resulting purified DNA-AuNP hybrids were re-suspended in buffer and stored under various environmental and buffer conditions. At designated time points the AuNPs were centrifuged and the supernatant fluorescence intensity was measured to quantify the fraction of released/degraded DNA.

The kinetics of DNA release is presented in Figure 2. The initial fractions of released DNA were close to zero for all the samples, suggesting that most of the free DNAs were removed for the freshly purified AuNPs. As shown in Figure 2A (red dots), if the AuNPs were stored at room temperature in an aqueous buffer containing $100 \mathrm{mM} \mathrm{NaCl}, 5 \mathrm{mM}$ HEPES, $\mathrm{pH}$ 7.6, 30\% of the fluorophore dissociated from the DNA1-AuNP conjugate after 15 days. In the same time period, over $50 \%$ of the DNA dissociated from DNA2-AuNP (Figure 2C). The kinetics roughly followed a linear relationship over time for both samples. We chose to test $100 \mathrm{mM} \mathrm{NaCl}$ because this is a commonly used salt concentration for DNAAuNP storage. These experiments suggest that there was a significant amount of DNA dissociation/cleavage from the AuNP surface in a normal storage/reaction buffer. Therefore, it is expected that the property of these purified DNA-AuNP conjugates will change significantly over time.

If the two DNAs are compared, one would intuitively expect that the amount of released fluorophore to be more for DNA1 than for DNA2, because in addition to the Au-thiol bond, any DNA degradation in DNA1 could contribute to the observed fluorescence. However, the opposite was observed. This can be explained by the following factors. First, the DNA degradation was minimal in the 15 days we studied, which has been confirmed by gel electrophoresis (vide infra). Therefore, most released fluorophore was through the Au-thiol bond cleavage. Second, with the fluorophore labels, it was straightforward to determine the DNA density on AuNPs. ${ }^{41,60}$ The average number of DNA2 on each $13 \mathrm{~nm}$ AuNP was determined to be $144 \pm 22$, which was more than $50 \%$ greater than that for DNA1 (92 \pm 9 on each AuNP). The rate of DNA dissociation should be proportional to the DNA density on the AuNP surface. Therefore, 
under otherwise identical conditions, more DNA2 should be released than DNA1 in the same time period. Finally, while the nucleotides right next to the thiols were thymine for both DNAs, the thymine on DNA2 had a covalently attached FAM fluorophore, which may affect the stability of the thiol-Au bond. ${ }^{46}$ Overall, the difference between these two DNAs were quite small and their behavior followed the same trend, suggesting that the time-dependent DNA dissociation should be general.
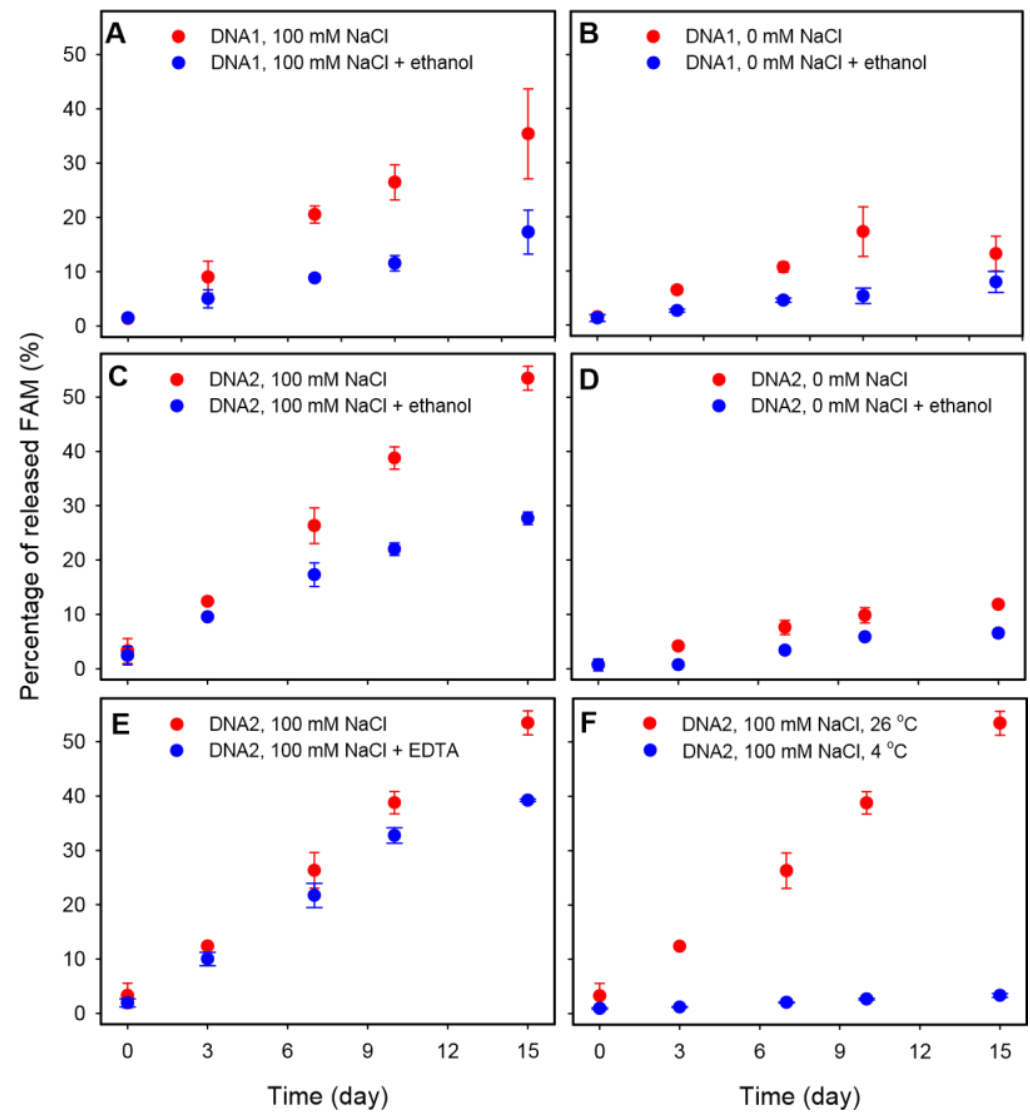

Figure 2. Dissociation of the FAM fluorophore from AuNP surface as a function of DNA sequence, salt, EDTA, temperature and ethanol. All the samples contained 5 mM HEPES, pH 7.6.

Effect of Salt. One parameter that can be easily controlled for the storage of DNA-AuNP conjugates is the solution ionic strength. Higher salt is known to decrease the colloidal stability of AuNPs and also to cause non-specific DNA mediated aggregation. ${ }^{51}$ Therefore, we next tested the effect of using a lower salt buffer with just $5 \mathrm{mM}$ HEPES at pH 7.6 (which should contain $2.5 \mathrm{mM} \mathrm{Na}^{+}$) and no additional $\mathrm{NaCl}$ was 
added (Figure 2B, D, red dots). Interestingly, we observed that the rate of DNA release was reduced to below $20 \%$ over 15 days for both DNA sequences.

It is known that a gradual increase of salt concentration can increase the conjugation efficiency of thiolDNA ${ }^{50}$ but no previous work has studied the effect of salt on the dissociation of DNA from Au surface. Jans et al. reported that the stability of SAMs containing polyethylene oxide (PEO) thiols were lower in phosphate buffered saline (PBS) than in water. PBS contains $150 \mathrm{mM} \mathrm{Na}^{+}$, which is similar to our high salt condition of $100 \mathrm{mM} \mathrm{Na}^{+}$. The discrepancy between these two systems may suggest that the DNA on the gold surface behaves quite differently from SAMs. One major difference is that the DNA is a polyanion. With heavily functionalized DNA, the AuNP surface is quite repulsive to negatively charged ions such as $\mathrm{OH}^{-}$, resulting in a decreased $\mathrm{OH}^{-}$concentration close to the surface, and this decrease can be described by the Boltzmann equation. This repulsive force is amplified at a lower ionic strength since the negative charges on DNA cannot be effectively screened. In the subsequent $\mathrm{pH}$-dependent studies we found that the dissociation of the thiol- $\mathrm{Au}$ bond was favored at higher $\mathrm{pH}$, suggesting that $\mathrm{OH}^{-}$can facilitate the reaction. Taking together, we attribute the deceased DNA dissociation at low salt to the decreased $\mathrm{OH}^{-}$concentration close to the gold surface.

Effect of pH. Both biochemical assays and storage can take place in different $\mathrm{pH}$ buffers. Studying the effect of $\mathrm{pH}$ can also help understand the mechanism of bond dissociation. Therefore, we next studied the effect of $\mathrm{pH}$. AuNPs modified with DNA1 was dispersed in $50 \mathrm{mM}$ of various buffer solutions with no additional $\mathrm{NaCl}$ present. After 3 and 6 days, the supernatant $\mathrm{pH}$ was adjusted to 8.3 before its fluorescence was measured since FAM is a pH-dependent fluorophore. As can be observed from Figure 3, more DNA was released on day 6 than on day 3, suggesting that the release was time dependent at all the tested $\mathrm{pH}$ buffers. At $\mathrm{pH} 4$ and 5, the amount of released DNA was the lowest while at $\mathrm{pH} 9$, the highest amount of release was observed. Therefore, high $\mathrm{pH}$ appeared to favor DNA dissociation. The only exception was at $\mathrm{pH}$ 6, at which the release was slightly higher than that at $\mathrm{pH}$ 7. This could be due to the use of different buffers. MES and Tris were used for $\mathrm{pH} 6$ and 7, respectively. 
The $\mathrm{pH}$-dependent stability of SAM was also studied on a planar gold surface using elliposometry. ${ }^{61}$ In that study, long alkyl thiol chains terminated with methyl, hydroxyl, carboxylic acid and amine were tested and all the samples showed a lower stability at higher $\mathrm{pH}$. However, we observed $\sim 30 \%$ DNA release in 6 days at $\mathrm{pH} 9$, but in the SAM case the monolayer was still quite stable at $\mathrm{pH} 9$. Release was observed only at $\mathrm{pH}$ higher than 12 . This $\mathrm{pH}$-dependent comparison between SAM and DNAfunctionalized Au surface suggests that while both systems share a similar dissociation mechanism but SAM has a much higher stability than DNA on gold. DNA does not form a compact monolayer due to a lack of lateral hydrophobic forces and thus can be attacked more easily.

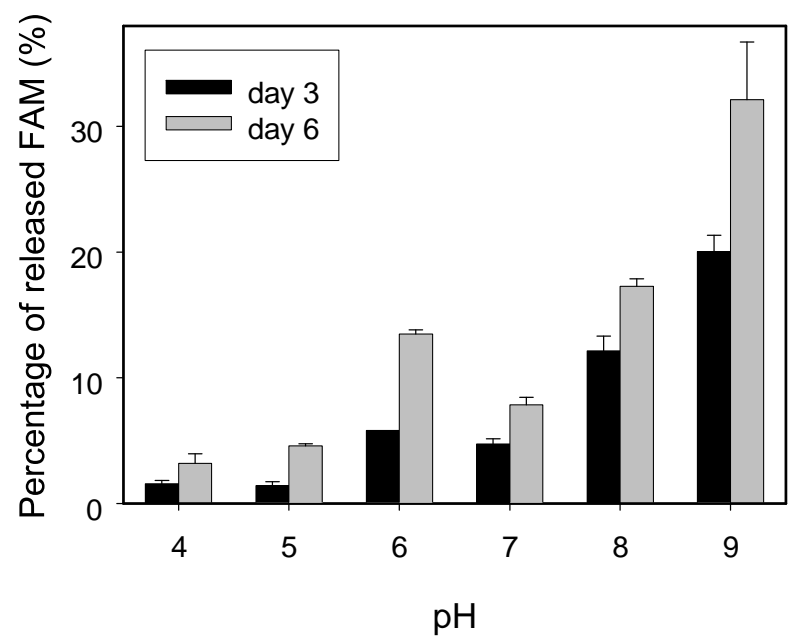

Figure 3. The effect of $\mathrm{pH}$ on the release of the FAM fluorophore into solution. The buffers $(50 \mathrm{mM}$ each) were acetate for $\mathrm{pH} 4$ and 5, MES for $\mathrm{pH} 6$, and Tris- $\mathrm{HCl}$ for $\mathrm{pH}$ 7-9.

Effect of Temperature and EDTA. To further optimize the storage conditions, two additional sets of samples were prepared with one containing $2 \mathrm{mM}$ EDTA and the other stored at $4{ }^{\circ} \mathrm{C}$. These conditions were chosen because they can be easily accessed in common laboratory settings. EDTA was intended to remove trace amount of divalent metal ions and act as a nuclease inhibitor. Both samples were functionalized with DNA2 and contained $100 \mathrm{mM} \mathrm{NaCl}$. As can be observed from Figure 2E, EDTA had 
little effects on the release kinetics and fast DNA dissociation was still observed. This is expected if DNA degradation was not responsible for the fluorophore release.

Interestingly, the sample stored at $4{ }^{\circ} \mathrm{C}$ showed drastically reduced release kinetics (Figure $2 \mathrm{~F}$ ). After 15 days, the amount of released fluorophore was less than $3 \%$ even in the presence of $100 \mathrm{mM} \mathrm{NaCl}$. This is consistent with previous reports that DNA dissociation is faster at higher temperature. ${ }^{59}$ The decreased rate of dissociation at lower temperature suggests that the cleavage of the thiol-Au bond should be an endothermic process. The above experiments indicate that the purified AuNPs were quite stable for a day or two. If the particles have to be stored for a longer time, they should be dispersed in a slightly acidic buffer with a low salt concentration and at low temperature.

Effect of Ethanol. Ethanol is a commonly used reagent for extracting, precipitating, and protecting DNA. At the same time, ethanol is also commonly used for cleaning surfaces. We recently demonstrated that DNA-directed assembly of such AuNPs was even faster in ethanol compared to that in water. ${ }^{62,63}$ Therefore, we are also interested in testing the effect of ethanol on the stability of the DNA-Au linkages. As shown in Figure 2A-D (blue dots), $80 \%$ ethanol (v/v) was able to reduce the fluorophore release by about half in all the tested DNA and salt conditions.

The stability of SAMs in ethanol has also been previously studied and it was found that the SAM stability was much lower in ethanol than in water. ${ }^{34,64,65}$ The mechanism of SAM desorption in ethanol was found to be through formation of disulfides. ${ }^{36}$ Ethanol is less polar than water and can therefore disrupt hydrophobic interactions in SAMs, making them less stable. For immobilized DNA, however, there was little hydrophobic interaction to begin with. In high salt conditions, DNA-functionalized AuNPs were aggregated in ethanol, which may also hinder DNA release. Taking together, while ethanol can damage SAMs, it showed a moderate protection effect on adsorbed DNA.

Effect of Other Solvents. Since ethanol showed a moderate protection effect, we are interested in testing other organic solvents. Previous studies on SAMs have shown that solvents like DMF and DMSO 
were effectively adsorbed on surface defect sites and can increase the activation energy for thiol desorption to inhibit SAM degradation. ${ }^{65}$

First we need to ensure that the solvents do not damage DNA-functionalized AuNPs. As shown in Figure 4A, the AuNPs were stable in $25 \%$ (v/v) of all tested solvents in the presence of $100 \mathrm{mM} \mathrm{NaCl}$, as indicated by the red color of dispersed AuNPs. By doubling the salt and solvent concentrations (Figure 4B), AuNPs aggregated in most solvents except for those dispersed in ethylene glycol, glycerol, or water. The aggregation was likely due to the decreased dielectric constants of solvents compared to water. Such aggregation, however, was reversible for most solvents. Upon centrifugation and removal of the supernatants, the AuNPs can be re-dispersed in water to give a red color (Figure 4C). Some AuNPs were lost for isopropanol and acetonitrile as their colors were much lighter compared to other solvents. These results suggest that DNA-functionalized AuNPs can be stably dispersed in most organic solvents.

We next prepared solutions with AuNPs dispersed in 40 or $80 \%$ of various solvents with no additional $\mathrm{NaCl}$ added, but all contained $5 \mathrm{mM}$ HEPES, $\mathrm{pH}$ 7.6. As can be observed in Figure 5, the effect of solvents on DNA dissociation was quite moderate. After 6 days, $10 \%$ release was observed in water. With $40 \%$ of solvents, most showed slightly decreased release. With $80 \%$, only DMF and ethylene glycol showed slightly more release than water. Therefore, changing the solvent has little effect on the stability of the thiol-Au linkage. 


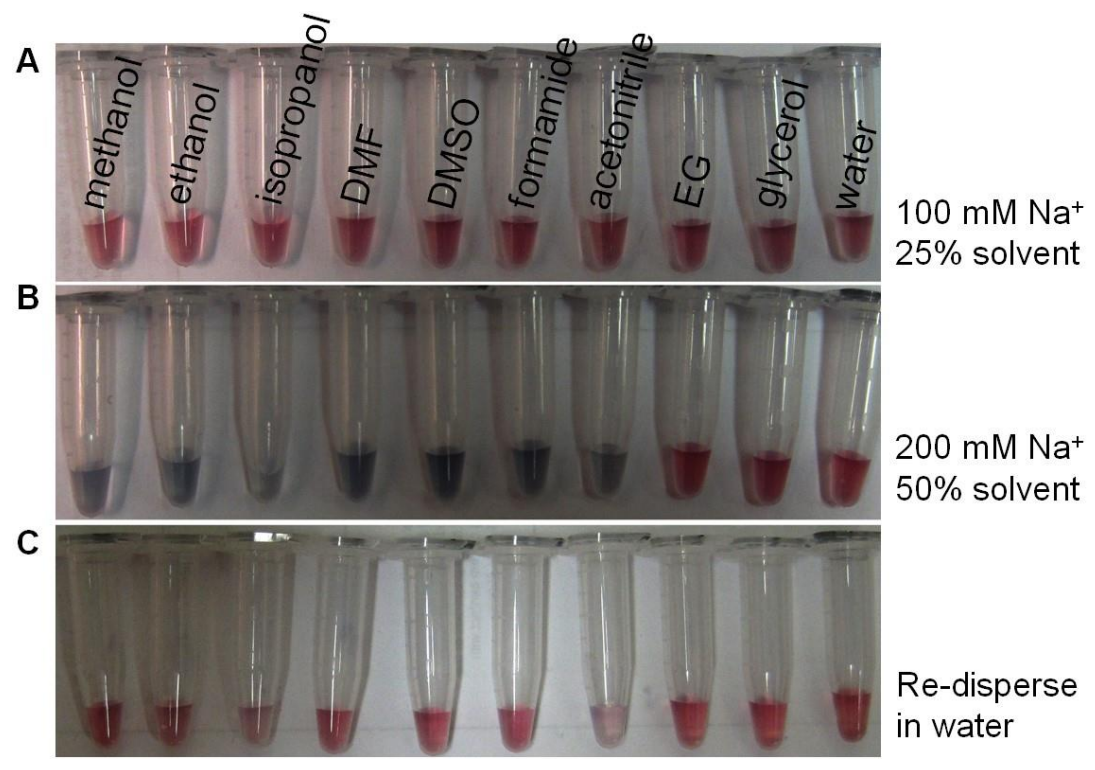

Figure 4. Photographs of DNA-functionalized AuNPs dispersed in various concentrations of organic solvents. The image in (C) was obtained by centrifugation of samples in (B) and then re-dispersing the AuNPs in water. $\mathrm{DMF}=$ dimethylformamide; $\mathrm{DMSO}=$ dimethyl sulfoxide; $\mathrm{EG}=$ ethylene glycol.

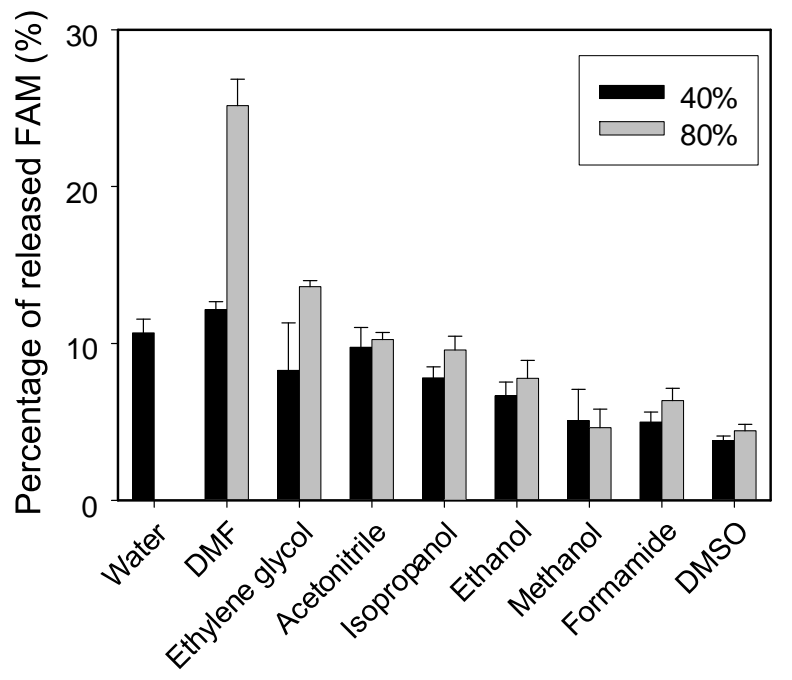

Figure 5. The effect of solvent on the release of the FAM fluorophore into solution. Each sample also contained 5 mM HEPES, pH 7.6.

DNA Degradation. The above dissociation experiments measured the supernatant fluorescence intensity. This gave information about the total number of released fluorophore but we could not tell whether the DNA phosphodiester bond was cleaved in the process. To exam DNA degradation during 
storage, DNA2-functionalized AuNPs were used. At designated time points, the AuNPs were collected and a high concentration of BME was added to displace the DNA2 on AuNPs. The displaced DNA2 was then analyzed by denaturing polyacrylamide gel electrophoresis. Since the fluorophore on DNA2 was close to the thiol modification, any DNA degradation should generate shorter DNA that can be detected by gel electrophoresis.

As shown in Figure 6, the first lane on the left is the freshly prepared free DNA2 and only a single band was observed, suggesting the high purity of the DNA. After mixing the DNA with AuNPs, a weak band at lower molecular weight can be observed even at day 0 under all tested conditions, and this additional band should be a degradation product. The amount of degradation, however, did not increase significantly over the time course of 15 days. Therefore, that the amount of DNA degradation was minimal. The intensity of the DNA2 band was clearly decreased for the sample with $100 \mathrm{mM} \mathrm{NaCl}$ stored at room temperature, which was consistent with the previous supernatant fluorescence measurement that $\sim 50 \%$ of DNA2 was released from the AuNP surface after 15 days. When stored at $4{ }^{\circ} \mathrm{C}$, little change in the band intensity was observed, confirming that the DNA integrity was maintained at low temperature.

Another observation from the gel experiment is that the band with ethanol showed a lower intensity compared to that in water. We know that the released fluorophore in ethanol was only about half of that released in water. Therefore, there should be more DNA on AuNPs in the presence of ethanol. The decreased gel band suggests that the BME displacement reaction was slower in ethanol. 


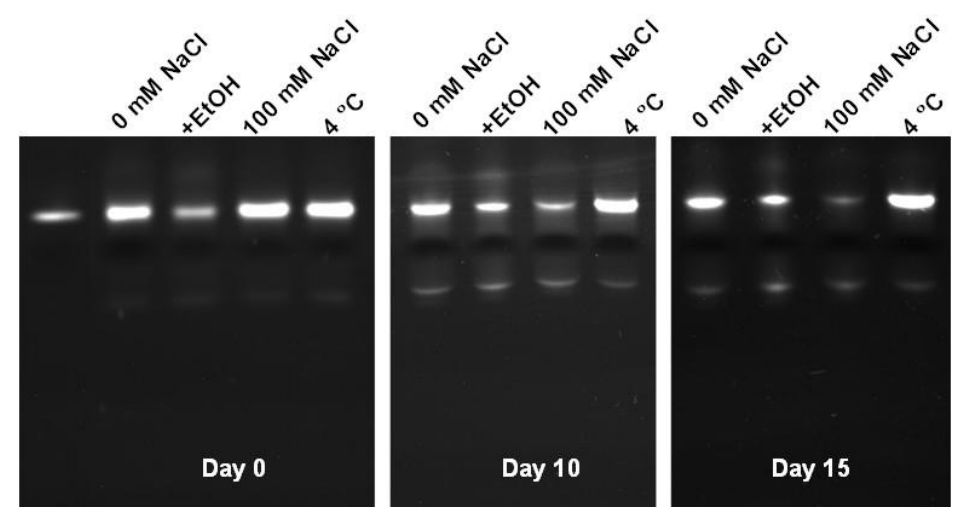

Figure 6. Denaturing polyacrylamide gel electrophoresis of DNA on AuNPs stored at different conditions. The first lane on the left for the day 0 gel was the pure DNA. The samples with ethanol (EtOH) did not contain any $\mathrm{NaCl}$. The sample in $100 \mathrm{mM} \mathrm{NaCl}$ also contained $2 \mathrm{mM}$ EDTA. The sample at $4{ }^{\circ} \mathrm{C}$ had a $\mathrm{NaCl}$ concentration of $100 \mathrm{mM}$.

\section{CONCLUSIONS.}

In summary we have systematically studied the dissociation of thiol-modified DNA from AuNP surface as a function of environmental and buffer conditions. Without special sterile techniques, we observed very little DNA degradation and most of the DNA release was attributed to the thiol-Au bond cleavage. It has been recently reported that AuNPs can protect attached DNA from enzymatic cleavage, ${ }^{66}$ and such protection may also contribute to our observation in this study. Under each storage condition, the release profile was compared with that for SAM. While there are similarities, due to the lack of lateral interactions within the immobilized DNA layer and the negatively charged DNA backbone, there are also many differences between these two systems. With this study, we conclude that DNA-functionalized AuNPs need to be purified and used freshly. If long-term storage is required, low salt, low $\mathrm{pH}$ and low temperature conditions are preferred.

ACKNOWLEDGMENT. Funding for this work is from the University of Waterloo and the Natural Sciences and Engineering Research Council (NSERC) of Canada. 


\section{REFERENCES}

(1) Mirkin, C. A.; Letsinger, R. L.; Mucic, R. C.; Storhoff, J. J., Nature 1996, 382, 607-609.

(2) Alivisatos, A. P.; Johnsson, K. P.; Peng, X.; Wilson, T. E.; Loweth, C. J.; Bruchez, M. P., Jr;

Schultz, P. G., Nature 1996, 382, 609-611.

(3) Storhoff, J. J.; Mirkin, C. A., Chem. Rev. 1999, 99, 1849-1862.

(4) Niemeyer, C. M., Angew. Chem., Int. Ed. 2001, 40, 4128-4158.

(5) Seeman, N. C., Nature 2003, 421, 427-431.

(6) Katz, E.; Willner, I., Angew. Chem., Int. Ed. 2004, 43, 6042-6108.

(7) Rosi, N. L.; Mirkin, C. A., Chem. Rev. 2005, 105, 1547-1562.

(8) Zhao, W.; Brook, M. A.; Li, Y., Chembiochem 2008, 9, 2363-2371.

(9) Liu, J.; Cao, Z.; Lu, Y., Chem. Rev. 2009, 109, 1948-1998.

(10) Lin, C.; Liu, Y.; Yan, H., Biochemistry 2009, 48, 1663-1674.

(11) Giljohann, D. A.; Seferos, D. S.; Daniel, W. L.; Massich, M. D.; Patel, P. C.; Mirkin, C. A., Angew. Chem. Int. Ed. 2010, 49, 3280-3294.

(12) Loweth, C. J.; Caldwell, W. B.; Peng, X.; Alivisatos, A. P.; Schultz, P. G., Angew. Chem., Int. Ed. 1999, 38, 1808-1812.

(13) Deng, Z.; Tian, Y.; Lee, S.-H.; Ribbe, A. E.; Mao, C., Angew. Chem., Int. Ed. 2005, 44, 35823585.

(14) Zhao, W.; Gao, Y.; Kandadai, S. A.; Brook, M. A.; Li, Y., Angew. Chem., Int. Ed. 2006, 45, 2409.

(15) Lee, J. H.; Wernette, D. P.; Yigit, M. V.; Liu, J.; Wang, Z.; Lu, Y., Angew. Chem. Int. Ed. 2007, 46, 9006-9010.

(16) Aldaye, F. A.; Sleiman, H. F., J. Am. Chem. Soc. 2007, 129, 4130-4131.

(17) Park, S. Y.; Lytton-Jean, A. K. R.; Lee, B.; Weigand, S.; Schatz, G. C.; Mirkin, C. A., Nature 2008, 451, 553-556.

(18) Nykypanchuk, D.; Maye, M. M.; van der Lelie, D.; Gang, O., Nature 2008, 451, 549-552.

(19) Sharma, J.; Chhabra, R.; Cheng, A.; Brownell, J.; Liu, Y.; Yan, H., Science 2009, 323, 112-116. 
(20) Rosi, N. L.; Giljohann, D. A.; Thaxton, C. S.; Lytton-Jean, A. K. R.; Han, M. S.; Mirkin, C. A., Science 2006, 312, 1027-1030.

(21) Liu, J.; Lu, Y., J. Am. Chem. Soc. 2003, 125, 6642-6643.

(22) Liu, J. W.; Lu, Y., Angew. Chem. Int. Ed. 2006, 45, 90-94.

(23) Elghanian, R.; Storhoff, J. J.; Mucic, R. C.; Letsinger, R. L.; Mirkin, C. A., Science 1997, 277, 1078-1080.

(24) Nam, J.-M.; Thaxton, C. S.; Mirkin, C. A., Science 2003, 301, 1884-1886.

(25) Medley, C. D.; Smith, J. E.; Tang, Z.; Wu, Y.; Bamrungsap, S.; Tan, W. H., Anal. Chem. 2008, $80,1067-1072$.

(26) Storhoff, J. J.; Lazarides, A. A.; Mucic, R. C.; Mirkin, C. A.; Letsinger, R. L.; Schatz, G. C., J. Am. Chem. Soc. 2000, 122, 4640-4650.

(27) Jin, R.; Wu, G.; Li, Z.; Mirkin, C. A.; Schatz, G. C., J. Am. Chem. Soc. 2003, 125, 1643-1654.

(28) Porter, M. D.; Bright, T. B.; Allara, D. L.; Chidsey, C. E. D., J. Am. Chem. Soc. 1987, 109, 3559-3568.

(29) Schoenfisch, M. H.; Pemberton, J. E., J. Am. Chem. Soc. 1998, 120, 4502-4513.

(30) Yang, Z.; Gonzalezcortes, A.; Jourquin, G.; Vire, J. C.; Kauffmann, J. M.; Delplancke, J. L., Biosens. Bioelectron. 1995, 10, 789-795.

(31) Flynn, N. T.; Tran, T. N. T.; Cima, M. J.; Langer, R., Langmuir 2003, 19, 10909-10915.

(32) Willey, T. M.; Vance, A. L.; van Buuren, T.; Bostedt, C.; Terminello, L. J.; Fadley, C. S., Surf. Sci. 2005, 576, 188-196.

(33) Peng, D. K.; Lahann, J., Langmuir 2007, 23, 10184-10189.

(34) Jans, K.; Bonroy, K.; De Palma, R.; Reekmans, G.; Jans, H.; Laureyn, W.; Smet, M.; Borghs, G.; Maes, G., Langmuir 2008, 24, 3949-3954.

(35) Qin, G. T.; Cai, C. Z., Chem. Comm. 2009, 5112-5114.

(36) Cortes, E.; Rubert, A. A.; Benitez, G.; Carro, P.; Vela, M. E.; Salvarezza, R. C., Langmuir 2009, 
$25,5661-5666$.

(37) Maciel, J.; Martins, M. C. L.; Barbosa, M. A., J. Biomed. Mater. Res. A 2010, 94A, 833-843.

(38) Vericat, C.; Vela, M. E.; Benitez, G.; Carro, P.; Salvarezza, R. C., Chem. Soc. Rev. 2010, 39, 18051834.

(39) Petrovykh, D. Y.; Kimura-Suda, H.; Whitman, L. J.; Tarlov, M. J., J. Am. Chem. Soc. 2003, 125, 5219-5226.

(40) Love, J. C.; Estroff, L. A.; Kriebel, J. K.; Nuzzo, R. G.; Whitesides, G. M., Chem. Rev. 2005, $105,1103-1169$.

(41) Hill, H. D.; Millstone, J. E.; Banholzer, M. J.; Mirkin, C. A., Acs Nano 2009, 3, 418-424.

(42) Li, Z.; Jin, R. C.; Mirkin, C. A.; Letsinger, R. L., Nucleic Acids Res. 2002, 30, 1558-1562.

(43) Dougan, J. A.; Karlsson, C.; Smith, W. E.; Graham, D., Nucleic Acids Res. 2007, 35, 3668-3675.

(44) Mei, B. C.; Oh, E.; Susumu, K.; Farrell, D.; Mountziaris, T. J.; Mattoussi, H., Langmuir 2009, 25, 10604-10611.

(45) Phares, N.; White, R. J.; Plaxeo, K. W., Anal. Chem. 2009, 81, 1095-1100.

(46) Storhoff, J. J.; Elghanian, R.; Mirkin, C. A.; Letsinger, R. L., Langmuir 2002, 18, 6666-6670.

(47) Zhao, W. A.; Chiuman, W.; Lam, J. C. F.; McManus, S. A.; Chen, W.; Cui, Y. G.; Pelton, R.;

Brook, M. A.; Li, Y. F., J. Am. Chem. Soc. 2008, 130, 3610-3618.

(48) Zhao, W.; Chiuman, W.; Brook, M. A.; Li, Y., Chembiochem 2007, 8, 727-731.

(49) Chompoosor, A.; Han, G.; Rotello, V. M., Bioconjug. Chem. 2008, 19, 1342-1345.

(50) Hurst, S. J.; Lytton-Jean, A. K. R.; Mirkin, C. A., Anal. Chem. 2006, 78, 8313-8318.

(51) Hurst, S. J.; Hill, H. D.; Mirkin, C. A., J. Am. Chem. Soc. 2008, 130, 12192-12200.

(52) Storhoff, J. J.; Elghanian, R.; Mucic, R. C.; Mirkin, C. A.; Letsinger, R. L., J. Am. Chem. Soc. 1998, 120, 1959-1964.

(53) Walczak, M. M.; Popenoe, D. D.; Deinhammer, R. S.; Lamp, B. D.; Chung, C. K.; Porter, M. D., Langmuir 1991, 7, 2687-2693. 
(54) Azzaroni, O.; Vela, M. E.; Martin, H.; Creus, A. H.; Andreasen, G.; Salvarezza, R. C., Langmuir 2001, 17, 6647-6654.

(55) Pesika, N. S.; Stebe, K. J.; Searson, P. C., Langmuir 2006, 22, 3474-3476.

(56) Madueno, R.; Garcia-Raya, D.; Viudez, A. J.; Sevilla, J. M.; Pineda, T.; Blazquez, M., Langmuir 2007, 23, 11027-11033.

(57) Murphy, J. N.; Cheng, A. K. H.; Yu, H. Z.; Bizzotto, D., J. Am. Chem. Soc. 2009, 131, 40424050.

(58) Musgrove, A.; Kell, A.; Bizzotto, D., Langmuir 2008, 24, 7881-7888.

(59) Herdt, A. R.; Drawz, S. M.; Kang, Y. J.; Taton, T. A., Colloid. Surface. B. 2006, 51, 130-139.

(60) Demers, L. M.; Mirkin, C. A.; Mucic, R. C.; Reynolds, R. A., III; Letsinger, R. L.; Elghanian, R.; Viswanadham, G., Anal. Chem. 2000, 72, 5535-5541.

(61) Kong, B.; Kim, Y.; Choi, I. S., B. Korean Chem. Soc. 2008, 29, 1843-1846.

(62) Smith, B. D.; Liu, J., J. Am. Chem. Soc. 2010, 132, 6300-6301.

(63) Dave, N.; Liu, J., J. Phys. Chem. B 2010, 114 15694-15699.

(64) Mohri, N.; Inoue, M.; Arai, Y.; Yoshikawa, K., Langmuir 1995, 11, 1612-1616.

(65) Yang, G.; Amro, N. A.; Starkewolfe, Z. B.; Liu, G.-Y., Langmuir 2004, 20, 3995-4003.

(66) Seferos, D. S.; Prigodich, A. E.; Giljohann, D. A.; Patel, P. C.; Mirkin, C. A., Nano Lett. 2009, 9 , 308-311. 